loams, it does not seem so incredible that the loess and clayey loam are the delta-like accumulation of great streams, fed from the glaciers on the north and the Tertiary silts on the west."

I am surprised to learn from Mr. Hershey's letter that in northwestern Illinois the 'upland loess' 'is present over the thick terrace-like deposits of true loess down along the streams.' Chamberlin "and Salisbury, as I understand, make the terraces subsequent to the former, and however that may be in that region, there is clear evidence from fossils and rearranged material that such is the case along the Missouri. It is a common thing for all terraces to be capped by a finer loam, the last deposition of the flood which laid down the coarser material below, or of some subsequent flood which barely submerged them.

Mr. Hershey assumes without question the preglacial age of the troughs of the Missouri and Mississippi through this region. This has not yet been proved. The evidence to the contrary is given at some length in my report which he reviewed, and I need not repeat here. I would add only a few words. The rock bottom of the Missouri through the State of Missouri, and of the Mississippi below the mouth of the Des Moines, is nowhere known to be lower than is known to be sometimes reached by 'the scour' in floods of the present day, viz., 80 or 90 feet.

The interesting preglacial channel west of Keokuk, first reported by General Warren, is interesting, but instead of proving that most of the present Mississippi channel is preglacial, rather shows the contrary, for its course at Quincy and below corresponds in depth and size with the new channel at Keokuk rather than the old one, and that has evidently been cut since the glacial epoch. We may as reasonably search for the continuation of the old channel toward the east as toward the south, for bed rock opposite Quincy is 45 feet below low water.

Before closing I would state that I am not over-confident concerning the Osage-Gasconade divide, and am only sorry that circumstances have not permitted my further study of the problems involved. But as far as our present knowledge goes, it still seems to me much more tenable than the theory which I understand Mr. Hershey to propose.

$$
\text { J. E. TODD. }
$$

StATE UNIVERSity, VeRMiLioN, S. D., May 31, 1897.

\section{A MONUMENT TO THE LATE BUYs-ballot.}

To THE Editor of Science: The Royal Dutch Meteorological Institute is about to remove from the old buildings at Utrecht, where, during forty years Professor C. H. D. BuysBallot labored so indefatigably for meteorology, to the new establishment at de Bilt, near Utrecht. Buys-Ballot, who may be called the founder of meteorological science in the Netherlands, is known to students of that science the world over from the law bearing his name, which connects the direction of the wind with the position of the storm center. His noble character, combined with a charming personality, endeared him to his colleagues, and won the respect and affection of a wide circle of acquaintances, which included the writer. A provisional committee, composed of his former associates, believing that the memory of such a man is honored outside of his own country, has invited an international committee to aid in obtaining funds for the erection at Utrecht of a monumental bust of the great meteorologist. The American members of this committee are Professor Willis L. Moore, Chief of the United States Weather Bureau at Washington, and the undersigned. Subscriptions sent to either one of us will be acknowledged and forwarded to the Dutch committee.

\section{A. LAWRENCE Rotch, \\ Director OF the BLUE HiLl METEOROLOGICAL OBSERVATORY, REAdVILle, Mass. ORGANIC SELECTION.}

I AM unable to agree with Mr. Robert M. Pierce that the passage he quotes from Mr. Herbert Spencer's 'Principles of Biology' sets forth the same conception that Professor Mark Baldwin dealt with in ScIEnce for April 33d. Mr. Spencer's position, I take it, is this: Acquired characters are inherited; there is a natural selection of acquirers, the fittest of whom survive to transmit their acquired characters; hence evolution is rendered more rapid than it would otherwise be. This is primarily 